Article

\title{
Extracellular Nucleotides Affect the Proangiogenic Behavior of Fibroblasts, Keratinocytes, and Endothelial Cells
}

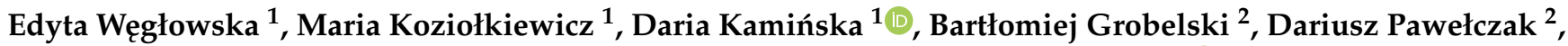 \\ Marek Kołodziejczyk ${ }^{1}$, Stanisław Bielecki ${ }^{1}$ and Edyta Gendaszewska-Darmach ${ }^{1, * \mathbb{D}}$
}

1 Institute of Molecular and Industrial Biotechnology, Faculty of Biotechnology and Food Sciences, Lodz University of Technology, Stefanowskiego 2/22, 90-537 Lodz, Poland; edytalaska4@gmail.com (E.W.); maria.koziolkiewicz@p.lodz.pl (M.K.); daria.kaminska@dokt.p.lodz.pl (D.K.); marek.kolodziejczyk@p.lodz.pl (M.K.); stanislaw.bielecki@p.lodz.pl (S.B.)

2 Department of Experimental Surgery, Medical University of Lodz, 93-513 Lodz, Poland; bartlomiej.grobelski@umed.lodz.pl (B.G.); darekpawelczak@o2.pl (D.P.)

* Correspondence: edyta.gendaszewska-darmach@p.lodz.pl; Tel.: +48-4-2631-3443

Citation: Węgłowska, E.; Koziołkiewicz, M.; Kamińska, D.; Grobelski, B.; Pawełczak, D.; Kołodziejczyk, M.; Bielecki, S.; Gendaszewska-Darmach, E. Extracellular Nucleotides Affect the Proangiogenic Behavior of Fibroblasts, Keratinocytes, and Endothelial Cells. Int. J. Mol. Sci. 2022, 23, 238. https://doi.org/ $10.3390 /$ ijms 23010238

Academic Editors: Roland Wohlgemuth and Elzbieta Kierzek

Received: 27 November 2021 Accepted: 22 December 2021 Published: 27 December 2021

Publisher's Note: MDPI stays neutral with regard to jurisdictional claims in published maps and institutional affiliations.

Copyright: (C) 2021 by the authors. Licensee MDPI, Basel, Switzerland. This article is an open access article distributed under the terms and conditions of the Creative Commons Attribution (CC BY) license (https:// creativecommons.org/licenses/by/ $4.0 /)$

\begin{abstract}
Chronic wound healing is currently a severe problem due to its incidence and associated complications. Intensive research is underway on substances that retain their biological activity in the wound microenvironment and stimulate the formation of new blood vessels critical for tissue regeneration. This group includes synthetic compounds with proangiogenic activity. Previously, we identified phosphorothioate analogs of nucleoside $5^{\prime}$-O-monophosphates as multifunctional ligands of $P 2 Y 6$ and $P 2 Y 14$ receptors. The effects of a series of unmodified and phosphorothioate nucleotide analogs on the secretion of VEGF from keratinocytes and fibroblasts, as well as their influence on the viability and proliferation of keratinocytes, fibroblasts, and endothelial cells were analyzed. In addition, the expression profiles of genes encoding nucleotide receptors in tested cell models were also investigated. In this study, we defined thymidine $5^{\prime}$-O-monophosphorothioate (TMPS) as a positive regulator of angiogenesis. Preliminary analyses confirmed the proangiogenic potency of TMPS in vivo.
\end{abstract}

Keywords: extracellular nucleotides; angiogenesis; purinergic receptors; phosphorothioate analogs

\section{Introduction}

Transmembrane G protein-coupled receptors (GPCRs) constitute a diverse and broad superfamily of proteins. Within GPCRs, significant academic and industry effort has been put into developing agonist and antagonist ligands for the $P 2 Y$ receptors that respond to extracellular nucleotides. The $P 2 Y$ receptors with eight subtypes $(P 2 Y 1, P 2 Y 2, P 2 Y 4$, $P 2 Y 6, P 2 Y 11, P 2 Y 12, P 2 Y 13$, and $P 2 Y 14$ ) recognized so far belong to the $\delta$-branch of class A GPCRs [1]. ATP is an agonist for P2Y2 and P2Y11 receptors; ADP activates P2Y1, P2Y12, and $P 2 Y 13$. UTP recognizes $P 2 Y 2$ and $P 2 Y 4$ while UDP is a ligand for the $P 2 Y 6$ receptor, and a nucleotide sugar conjugate (UDP-glucose) is an agonist for the P2Y14. Based on their sequence similarity, the $P 2 Y$ receptors have been grouped into two subfamilies, namely P2Y1, P2Y2, P2Y4, P2Y6, and P2Y11 coupled directly to Gq protein and P2Y12 P2Y13, and $P 2 Y 14$ coupled to Gi/o protein. P2Y11 receptors' activation also stimulates adenylate cyclase to generate cAMP [2].

An increasing number of experimental data supports the idea that a range of native $P 2 Y$ ligands is major regulators of vascular cell functions. Especially, $P 2 Y 1, P 2 Y 2$, and $P 2 Y 12$ activation were shown to be implicated in the process of angiogenesis, an essential aspect of many non-healing wound $[3,4]$.

In intact tissues, the microvasculature remains in a state of homeostasis to supply oxygen and nutrients and remove carbon dioxide and waste products. Upon injury, the microvasculature is disrupted, leading to fluid accumulation, inflammation, and the devel- 
opment of hypoxia [5]. Additionally, the healing process may vary depending on the type of wound and additional unfavorable conditions. Treatment of chronically healing wounds is a serious medical problem due to the prevalence and frequent complications. It primarily affects elderly patients, seriously limiting their quality of life. Chronic wounds, including ulcers and bedsores, are also a serious complication of many diseases associated with the local reduction of blood flow in venous and arterial vessels and microcirculation. Arterial hypertension, obesity, infections, and diabetes may also be contributing factors. Hyperglycemia reduces the proliferation rate of keratinocytes, fibroblasts, and endothelial cells, which are found in the skin and are therefore directly involved in the healing process. Moreover, hyperglycemic conditions favor the increase in reactive oxygen species (ROS) [6]. Reduced angiogenesis in chronic venous ulcers was also associated with a decreased expression of various angiogenic growth factors, especially vascular endothelial growth factor (VEGF-A) [6], increased proteolysis of VEGF-A [7], as well as increased levels of soluble VEGF receptor, which may serve to neutralize VEGF-A activity [8].

Great progress has allowed for the synthesis of many healing-accelerating molecules intending to induce therapeutic angiogenesis. In particular, growth factors were a promising therapeutic strategy since in vivo these proteins play a critical role in the wound healing process. Unfortunately, many growth factor-based therapies have not shown clear benefits in clinical trials. The limited clinical efficacy of protein growth factors is associated with inactivation by the local action of proteases [9] or the development of resistance to angiogenic growth factors during the development of vascular disease and the aging process [10]. Recent advances in our understanding of chronic wound biology have led to the development of small-molecular therapies that promote angiogenic activity and modulate the repair process with exciting potential for clinical application [11]. Many literature data show that nucleotides secreted from cells into the extracellular space in response to damage take part in all stages of wound healing by activating the appropriate nucleotide receptors [12]. However, the therapeutic potential of unmodified nucleotides is limited due to the rapid degradation by numerous extracellular enzymes, which significantly reduces their duration of action and thus also their effectiveness. These enzymes include members of ecto-NTPDases (ecto-nucleoside triphosphate diphosphohydrolases), ectoNPPs (ecto-nucleotide pyrophosphatase/phosphodiesterase), ecto-alkaline phosphatases, and ecto-5' -nucleotidases [13]. To overcome these limitations, attempts have been made to increase the stability of nucleotides, e.g., by synthesizing phosphorothioate analogs of nucleotides. The studies on the stability of phosphorothioate analogs of nucleotides have shown that replacing an oxygen atom with sulfur in a phosphate group conferred significant resistance to enzymatic degradation by extracellular enzymes [14].

We have shown previously that nucleoside $5^{\prime}$-O-phosphorothioate analogs, namely $\mathrm{UTP} \gamma \mathrm{S}, \mathrm{UTP} \alpha \mathrm{S}$, and ATP $\gamma \mathrm{S}$, accelerated VEGF release and migration of human HaCaT keratinocytes. The potency of phosphorothioate analogs of ATP and UTP correlated with the highest P2Y2 receptor expression by the HaCaT cell line [15]. In the present study, we tested the ability of unmodified nucleotides (ADP, ATP, UDP, and UTP) and their phosphorothioate analogs (ADP $\beta S, \mathrm{UDP} \beta S, \mathrm{ATP} \gamma \mathrm{S}$, and UTP $\gamma \mathrm{S}$ ) to stimulate secretion of VEGF, a key factor in angiogenesis, from keratinocytes and fibroblasts, as well as their influence on the process of survival and proliferation of keratinocytes, fibroblasts and endothelial cells. The selection of these cell types was determined by their significant participation in the angiogenesis and wound healing processes [16]. The presented hereby research was extended to $5^{\prime}$-monophosphorothioate analogs (AMPS, CMPS, TMPS, and UMPS) since we have shown that nucleoside $5^{\prime}$-O-monophosphorothioates can also act as P2Y ligands $[17,18]$. The expression pattern of P2 receptors quantified by quantitative RT-PCR analysis was also estimated. 


\section{Materials and Methods}

\subsection{Tested Compounds}

ADP, ATP, UDP, and UTP were purchased from Sigma-Aldrich (Merck KGaA, Darmstadt, Germany). Phosphorothioate analogs of nucleotides (TMPS, AMPS, CMPS, UMPS, ADP $\beta$, $\mathrm{UDP} \beta \mathrm{S}, \mathrm{ATP} \alpha \mathrm{S}, \mathrm{ATP} \gamma \mathrm{S}, \mathrm{UTP} \alpha \mathrm{S}, \mathrm{UTP} \gamma \mathrm{S}$ ) were obtained from BioLog (Bremen, Germany).

\subsection{Cell Cultures}

All cells were cultured under standard conditions at $37^{\circ} \mathrm{C}$ in a humidified atmosphere of $95 \%$ air and $5 \% \mathrm{CO}_{2}$. Most of the culture reagents were obtained from Life Technologies (Carlsbad, CA, USA). Otherwise, the source is given in parentheses. Moreover, the culture media were supplemented with antibiotics, namely $100 \mathrm{U} / \mathrm{mL}$ of penicillin (Polfa Tarchomin, Warsaw, Poland) and $100 \mu \mathrm{g} \mathrm{ml}$ of streptomycin (Polfa Tarchomin, Warsaw, Poland).

\subsubsection{HaCaT Cell Line}

The immortal human keratinocyte HaCaT cell line was purchased from Leibniz Institute DSMZ-German Collection of Microorganisms and Cell Cultures (Braunschweig, Germany). Cells were cultured in Dulbecco's modified Eagle's medium (DMEM) supplemented with $10 \%$ fetal calf serum (FCS) containing $100 \mathrm{IU} / \mathrm{mL}$ of penicillin and $100 \mu \mathrm{g} / \mathrm{mL}$ of streptomycin.

\subsubsection{HUVECs}

Human umbilical vein endothelial cells (HUVECs) were purchased from Cascade Biologics, Inc. (Portland, OR, USA). Cells were grown in culture vessels coated with a $1 \%$ gelatin (Sigma-Aldrich) solution dissolved in phosphate-buffered saline (PBS, Thermo Fisher Scientific, Waltham, MA, USA). Growth medium consisted of a mixture of RPMI 1640 medium with the addition of $20 \%$ fetal bovine serum (FBS) and LSGS (low serum growth supplement) in the amount of $1 \mathrm{~mL}$ per $50 \mathrm{~mL}$ of medium. The final concentrations of LSGS substances in the culture medium were as follows: $2 \% \mathrm{FBS}, 1 \mu \mathrm{g} / \mathrm{mL}$ of hydrocortisone, $10 \mathrm{ng} / \mathrm{mL}$ of hEGF (human epidermal growth factor), $3 \mathrm{ng} / \mathrm{mL}$ of basic fibroblast growth factor bFGF (basic fibroblast growth factor), $10 \mu \mathrm{g} / \mathrm{mL}$ of heparin.

\subsubsection{Human Dermal Fibroblasts}

Human dermal fibroblasts, adult (HDF) were acquired from the Life Technologies collection. Cells were grown in Medium 106 supplemented with LSGS in the amount of $1 \mathrm{~mL}$ per $50 \mathrm{~mL}$ of medium.

\subsection{Expression of P2Y Genes with Reverse Transcription Quantitative Polymerase Chain Reaction}

Extraction of the total RNA from HUVECs and HDFs was performed with the RNeasy ${ }^{\circledR}$ Mini Kit (QIAGEN, Venlo, The Netherlands). Subsequently, RNA was purified with Amplification Grade DNase I (Sigma-Aldrich) and then reverse-transcribed to with $\mathrm{RT}^{2}$ First Strand Kit (SABioscences, Frederick, MD, USA). All primers were designed using the NCBI's Primer-BLAST software (National Center for Biotechnology Information, Bethesda, MD, USA) based on P2Y sequences from the GenBank database (Table 1) and purchased from Genomed (Warsaw, Poland). Real-time RT-PCR was conducted using SYBR ${ }^{\circledR}$ Greenbased RT ${ }^{2}$ qPCR Master Mix (SABioscences, Frederick, MD, USA) with a Chromo 4 detection system (Hercules, Bio-Rad, CA, USA). cDNA representing 6 ng per sample of total RNA was subjected to 40 cycles of PCR amplification. Samples were first incubated at $95^{\circ} \mathrm{C}$ for $15 \mathrm{~s}$, then at $60^{\circ} \mathrm{C}$ for $30 \mathrm{~s}$, and finally at $72{ }^{\circ} \mathrm{C}$ for $30 \mathrm{~s}$. The PCR products were electrophoretically separated in a 1.0\% agarose gel in Tris/borate/EDTA containing $0.5 \mu \mathrm{g} / \mathrm{mL}$ ethidium bromide. Housekeeping GAPDH gene was were selected as endogenous controls to correct potential variation in RNA loading. Expression of nucleotide receptors was normalized to GAPDH and the P2Y6 receptor was chosen as a reference calibrator for giving relative expression values. The amount of target gene expression level was calculated with 
Livak's method as $2^{-\Delta \Delta \mathrm{Ct}}$, where $\Delta \Delta \mathrm{C}_{\mathrm{t}}=\left[\mathrm{C}_{t}(\right.$ target $\left.)-\mathrm{C}_{t}(\mathrm{GAPDH})\right]$ sample $-\left[\mathrm{C}_{t}\right.$ (target $)$ $-\mathrm{C}_{t}(\mathrm{GAPDH}]$ calibrator.

Table 1. Sequence of primers used in RT-qPCR reaction.

\begin{tabular}{cccc}
\hline Gene & NCBI Reference Sequence & Forward Primer & Reverse Primer \\
\hline$P 2 Y 1$ & NM 002563 & CGGAAAGTTATCCGCGGCGGT & GGGCTATCGGGCAAGCCAGC \\
$P 2 Y 2$ & NM 176072 & GAGGAGCCCCTTGTGGCAGC & CACGCCCAGCCTCCAGCATTTT \\
$P 2 Y 4$ & NM 002565 & TGCTGGGCTTGGGCCTTAACG & GGCCGTTGCATCCCAGGGTC \\
$P 2 Y 6$ & NM 176798 & ATGCCTGCTCCCTGCCCCTG & GGCGAAGTCGCCAAAGGGCC \\
$P 2 Y 11$ & NM 002566 & ACAGAGCGTATAGCCTGGTG & TGTGGTAGGGCACATAGGA \\
$P 2 Y 12$ & NM 022788 & TCTGCGCCTGGTAACACCAGTCT & AACAGGACAGTGTAGAGCAGTGGGA \\
$P 2 Y 13$ & NM 176894 & GGTCAGCAAGACCTCTGAAA' & AAGGCATTGCTGAGTAGGTG \\
$P 2 Y 14$ & NM 001081455 & TGAATCCTGCTCTCAGAACC & AGGCTCATCACAAAGTCAGC \\
$G A P D H$ & NM 002046 & AAGGCTGGGGCTCATTTGCAGG & GCCAGGGGTGCTAAGCAGTTGG \\
\hline
\end{tabular}

\subsection{Cellular Metabolic Activity}

Cells were seeded into 96-well cell culture plates at a density of $1 \times 10^{4}$ cells/well in $100 \mu \mathrm{L}$ of complete culture medium. On the following day, cells were washed with PBS and $100 \mu \mathrm{L}$ of fresh serum-free medium was added. Subsequently the fasting medium was supplemented with a respective nucleotide added to a final concentration of $100 \mu \mathrm{M}$ and $48 \mathrm{~h}$ later $10 \mu \mathrm{L}$ of Presto Blue ${ }^{\circledR}$ cell viability reagent (Life Technologies, Carlsbad, CA, USA) was applied. Following 80 min incubation time, cell viability was determined by measuring the fluorescent signal $(E x / E m=530 / 590 \mathrm{~nm})$ on a Synergy 2 microplate reader (BioTek, Winooski, VT, USA). The obtained fluorescence magnitudes were used to calculate cell viability expressed as a percent of the viability of the untreated control cells.

\subsection{Proliferative Activity (DNA Quantification Assay)}

DNA content was measured using a CyQUANT Direct Cell Proliferation Assay (Life Technologies). CyQUANT detection reagent dye was added to the wells in a volume of $50 \mu \mathrm{L}$, incubated for $60 \mathrm{~min}$ and the fluorescence signal $(\mathrm{Ex} / \mathrm{Em}=485 / 528 \mathrm{~nm})$ detected using a Synergy 2 microplate reader. The obtained fluorescence magnitudes were used to calculate cell proliferation expressed as a percent of the proliferation of the untreated control cells.

\subsection{Quantification of VEGF-A Secretion}

Human VEGF protein was measured in culture media using the VEGF Human ELISA Kit (Life Technologies). Briefly, cells $\left(3 \times 10^{4}\right.$ cells per well) were seeded into 96-well plate in complete medium. After $24 \mathrm{~h}$ of incubation cells were starved for another $24 \mathrm{~h}$ in the culture medium without serum and subsequently treated with tested nucleotides added to a final concentration of $100 \mu \mathrm{M}$ for another $24 \mathrm{~h}$. Finally, cell culture supernatants were collected and VEGF levels were determined according to the manufacturer's protocol.

\subsection{Determination of Angiogenesis In Vivo}

All experimental procedures were approved by the Animal Bioethical Committee of Medical University of Lodz (no. 579/2011). Young adult Wistar rats (2-3 months; $n=6$ ) were kept separately in cages before and after surgical procedures at constant room temperature in the animal house of Medical University of Lodz, Poland. Rats were fed a normal chow diet and kept under a controlled $12 \mathrm{~h}$ light/dark cycle. Bionanocellulose scaffolds were produced by Komagataeibacter xylinus in stationary conditions according to the procedure published previously [17]. BNC membranes were then cut into slices with dimensions of $1 \times 1 \times 0.3 \mathrm{~cm}$, sterilized by autoclaving at $121{ }^{\circ} \mathrm{C}$ and then kept in PBS. Before implantation BNC membranes were soaked with sterile TMPS solution $(0.7 \mathrm{mg} / \mathrm{scaffold})$ or with PBS. The rats were weighed and anesthetized by administering ketamine (intramuscularly) at a concentration of $20 \mathrm{mg} / \mathrm{kg}$ c.c. The rat back hairs were 
shaved with the underlying skin cleaned and sterilized. To implant the scaffolds, two 1-cm incisions were cut on the dorsal section of each rat. Two BNC scaffold samples (control and with TMPS) were separately and implanted into each rat. The incisions were then sutured using MonosofTM 4/0 monofilament nylon sutures. All animals were then monitored by animal care services. After 30 days post implantation the rats were euthanized by giving an overdose of ketamine delivered as previously. The dorsal skin was carefully resected and sections containing cellulose scaffolds were photographed.

\subsection{Statistical Analysis}

Statistical analysis was performed using GraphPad Prism 6.0 software (GraphPad Software, Inc., La Jolla, CA, USA) and data are presented as the mean \pm SD of at least three independent experiments. Statistical differences between two groups were analyzed by one-way ANOVA with Bonferroni post hoc test. Differences between groups were rated significant at a probability error $p<0.05\left(^{*}\right), p<0.01\left({ }^{* *}\right), p<0.001\left(^{* * *}\right)$, and $p<0.0001\left(^{* * *}\right)$. $p<0.05\left(^{*}\right)$ was regarded as statistically significant.

\section{Results}

\subsection{Expression of Genes Encoding P2Y Receptors in HUVECs and HDF Cells}

So far, there are little data available in the literature on the quantitative analysis of the expression of nucleotide receptors in cells. Moreover, the relatively recently discovered P2Y12, P2Y13, and P2Y14 receptors were mainly not considered in the studies. Our previous studies revealed that in human HaCaT keratinocytes, P2Y2 showed the highest expression of all receptors studied. We observed about two times lower level of P2Y6 and a small amount of P2Y1 transcript. Expression of other P2Y4 and P2Y11-14 was also detected, but the distribution was much lower [15]. Hereby, RT-qPCR analyzes of P2Y genes were performed for human umbilical vein endothelial cells (HUVECs) and human primary fibroblasts isolated from adult skin (HDF) due to their crucial role in the angiogenesis process. The relative expression was compared with the GAPDH housekeeping gene and $P 2 Y 6$ was used as a calibrator (i.e., expression of each receptor was demonstrated as a ratio of $P 2 Y 6$ ) to illustrate the expression of $P 2$ receptors relative to each other.

We found that HUVECs expressed six P2Y subtypes (Figure 1A). The P2Y6 gene shows the highest level of expression. The genes encoding P2Y1 and P2Y14 receptors were next in terms of intensity of expression, followed by P2Y4, P2Y2, and P2Y11. Expression of P2Y12 and P2Y13 genes was not detected. In HDF fibroblasts, the mRNA of all known P2Y receptors was detected (Figure 1B). As in the case of HUVECs, in HDFs the expression of P2Y 6 was seen at the highest level. However, these cells also expressed the P2Y1 at a high level. A significantly lower expression of the P2Y14 gene compared to P2Y1 and P2Y6 and a significantly lower expression of the remaining P2Ys was also detected.
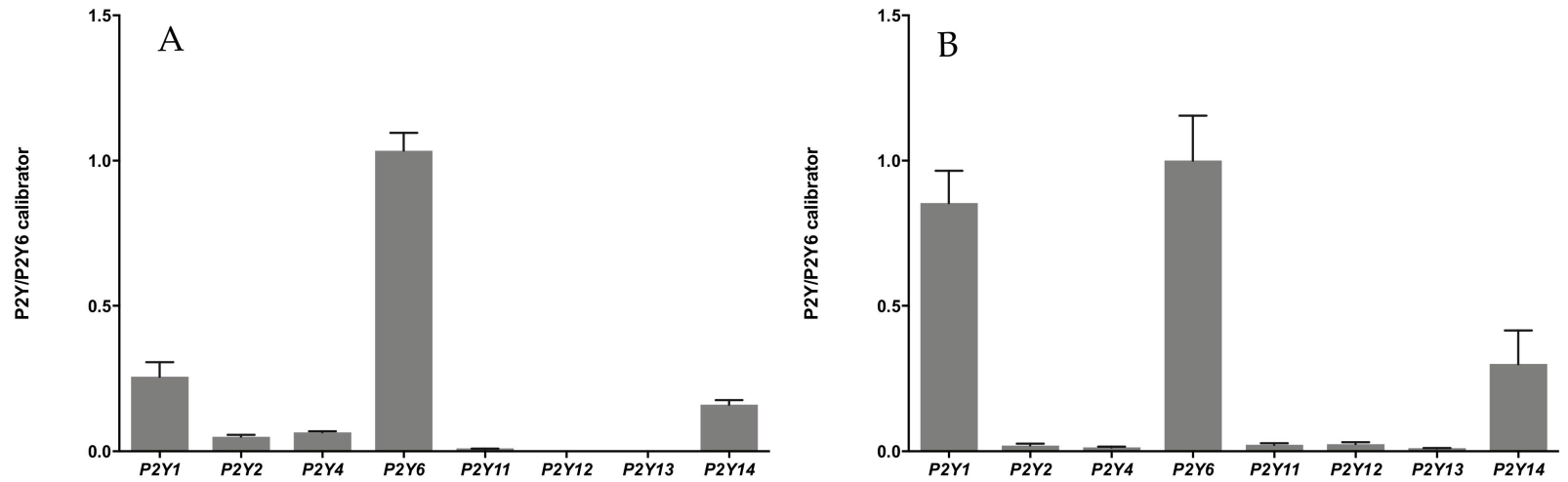

Figure 1. Comparison of expression patterns of genes encoding $P 2 Y$ receptors in HUVECs (A) and HDF (B) cells. The expression analyzed by the $\Delta \Delta C_{t}$ method was normalized to GAPDH and samples were calibrated by $P 2 Y 6$. Bar graphs show the results from at least three independent experiments for each receptor (the mean $\pm \mathrm{SD}$ ). 


\subsection{Cellular Metabolic Activity in the Presence of Extracellular Nucleotides}

Our research used a rezasurin-based metabolic assay, the PrestoBlue ${ }^{\circledR}$ test, to assess cell numbers after treatment with tested nucleotides. The resazurin-based assays use the mitochondrial activity to reduce the nonfluorescent blue resazurin to the fluorescent pink resorufin [18]. The results proved that unmodified nucleotides and their phosphorothioate analogs did not cause cytotoxicity against HUVEC endothelial cells, human dermal fibroblasts, and human HaCaT keratinocytes (Figure 2). In some cases, after 24 and $48 \mathrm{~h}$ of incubation, we even observed the stimulation of cell growth slightly exceeding $20 \%$ in the case of HUVECs and HDF. The highest stimulation of metabolic activity was observed in HaCaT cells and UTP, UTP $\alpha$ S, UTP $\gamma$ S, UDP, UDP $\beta$ S, and ADP $\beta$ S demonstrated the most increased activity.
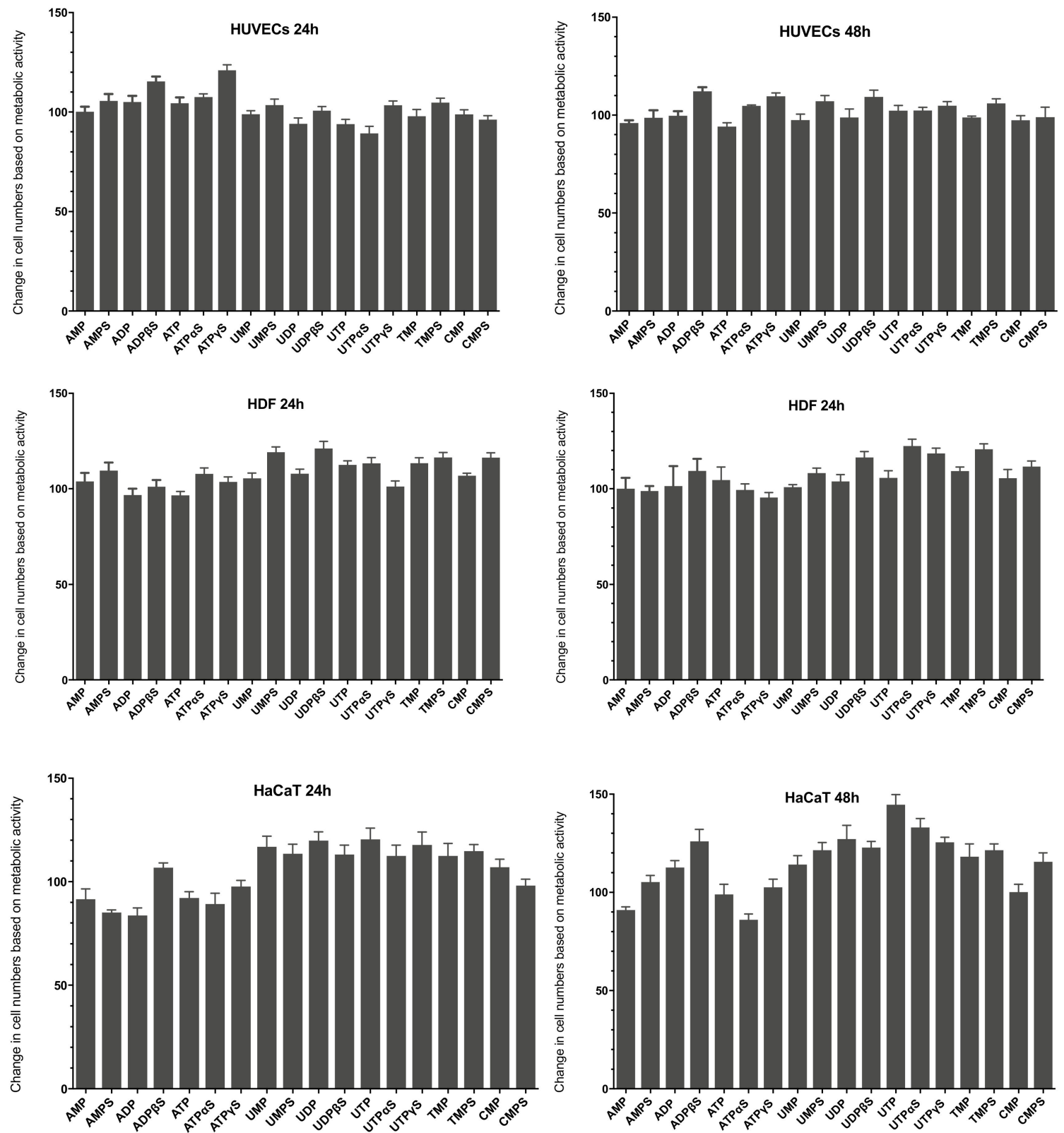

Figure 2. The effect of nucleotides and their phosphorothioate analogs on the metabolic activity of HUVECs, HDFs, and HaCaT cells after 24 and $48 \mathrm{~h}$ of incubation. Cell viability was analyzed using the PrestoBlue ${ }^{\circledR}$ test (Life Technologies, Carlsbad, CA, USA) for a concentration of $100 \mu \mathrm{M}$ of the tested compounds. Results are presented as mean values derived from at least three independent experiments $\pm \mathrm{SD}$. 


\subsection{Cellular Proliferation in the Presence of Extracellular Nucleotides}

Our studies also employed the fluorometric CyQUANT ${ }^{\circledR}$ assay (Life Technologies, Carlsbad, CA, USA) to determine DNA content reflecting proliferative activity, which is a critical feature regarding the survival of cells (Figure 3). It was shown in some studies that metabolic assays were used to quantify changes in cell growth that may not accurately reflect cellular proliferation rates [18]. The CyQUANT ${ }^{\circledR}$ test contains a cyanine dye characterized by a low intrinsic fluorescence and significant fluorescence enhancements upon binding to nucleic acid [19].
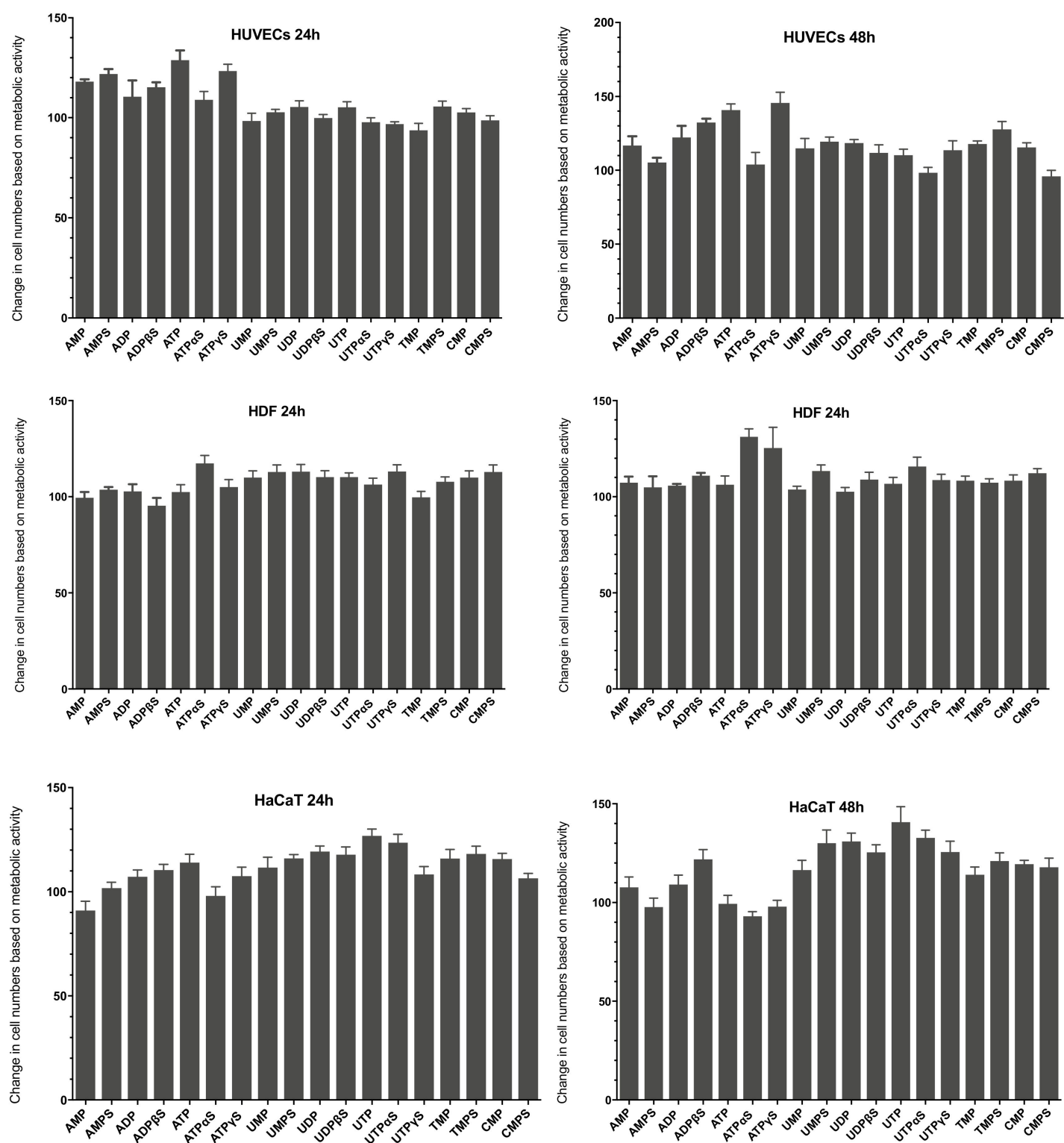

Figure 3. The effect of nucleotides and their phosphorothioate analogs on the proliferation of HUVECs, HDFs, and HaCaT cells after 24 and $48 \mathrm{~h}$ of incubation. Cell viability was analyzed using the CyQUANT ${ }^{\circledR}$ (Life Technologies, Carlsbad, CA, USA) test for a concentration of $100 \mu \mathrm{M}$ of the tested compounds. Results are presented as the mean value derived from at least three independent experiments \pm SD data.

Analysis of HUVECs proliferation showed that some of the nucleotides tested have a more significant impact on this process than the metabolic activity tested with the PrestoBlue ${ }^{\circledR}$ assay. After $24 \mathrm{~h}$, stimulation of proliferation exceeding $20 \%$ was caused by AMPS and ATP and its analog, ATP $\gamma$ S. After $48 \mathrm{~h}$, ATP and ATP $\gamma \mathrm{S}$ were the most 
active, inducing proliferation stimulation at $41 \%$ and $46 \%$. A high level of proliferation was also demonstrated after incubating cells with ADP, ADP $\beta S$ as well as some mononucleotide analogs, namely TMPS and UMPS. As in the case of the metabolic activity test, the proliferation of human HDF fibroblasts was only slightly stimulated by most of the nucleotides tested. The amount of synthesized DNA showed statistically significant changes in proliferation; however, the stimulation level was not high. No significant increase in the proliferation level of HDF fibroblasts was observed within $24 \mathrm{~h}$. After $48 \mathrm{~h}$ of incubation of cells with compounds, results indicated that ATP $\alpha$ S and ATP $\gamma S$ increased the proliferation of these cells by around $30 \%$. In addition, a slight effect of nucleotides on the expansion of human HaCaT keratinocytes was observed. After $24 \mathrm{~h}$, only thymidine and uridine nucleotides and their analogs increased proliferation by approx. $20 \%$. After $48 \mathrm{~h}$, uridine-containing compounds showed the highest activity.

\subsection{The Influence of Extracellular Nucleotides on the Secretion of the Proangiogenic Factor VEGF-A}

To measure the quantity of VEGF in the conditioned medium from HaCaT cells, we employed an ELISA kit specific for the most frequent type of VEGF isoforms, namely VEGF-A. VEGF-A concentration was measured after $24 \mathrm{~h}$ of incubation with extracellular nucleotides. We found that under standard culture conditions, HDFs produced VEGF at the average level of $198.0 \mathrm{pg} / \mathrm{mL} / 24 \mathrm{~h}$ per $3 \times 10^{4}$ cells. Most of the nucleotides studied had a stimulating effect on the secretion of VEGF-A protein. Nucleoside monophosphorothioates appeared to be the most active in stimulating fibroblasts to secrete VEGF-A (Figure 4). The most potent TMPS and CMPS caused more than a twofold increase in the concentration of secreted VEGF-A, while their unmodified counterparts did not affect the secretion of this protein). A high increase was also observed after incubating the cells with AMPS, UMPS, UDP $\beta S$, and ATP $\gamma$ S. The remaining compounds did not cause statistically significant differences in the concentration of the analyzed proangiogenic factor (Figure $4 \mathrm{~A}$ ).

We previously showed that treatment with UTP, UTP $\alpha$, and UTP $\gamma S$ strongly induced VEGF production in HaCaT cells [15]. Therefore, in this work we also checked the potential of nucleoside monophosphates and monophosphorothioates to stimulate VEGF secretion in keratinocytes. Untreated HaCaT cells produced an average of $289.3 \mathrm{pg} / \mathrm{mL} / 24 \mathrm{~h}$ per $3 \times 10^{4}$ cells of VEGF-A. Incubation in the presence of specific nucleotides, especially their phosphorothioate analogs, significantly increased the production of VEGF-A. In the latter group, TMPS and AMPS had the greatest potency (Figure 4B) and caused an increase in the amount of VEGF-A released by approx. $100 \mathrm{pg} / \mathrm{mL} / 24 \mathrm{~h}$ per $3 \times 10^{4}$ cells, which is approx. $30 \%$ of the rise.

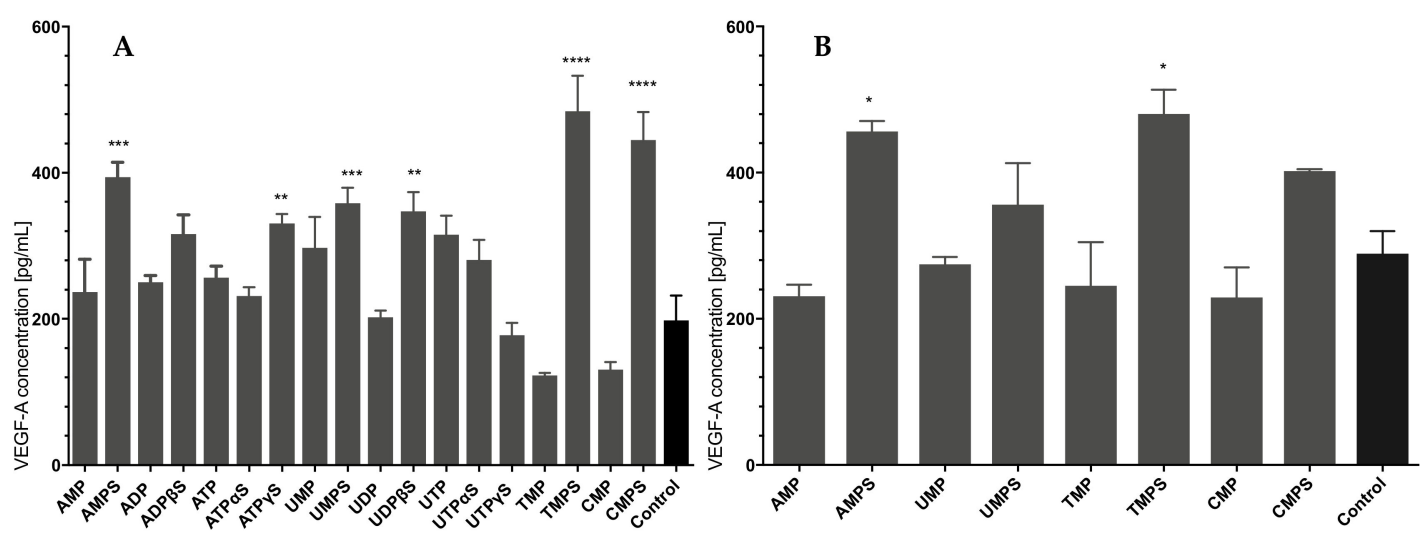

Figure 4. The effect of nucleotides and their phosphorothioate analogs on the VEGF-A secretion in HDF (A) and HaCaT (B). VEGF concentration was assessed using ELISA for $100 \mu \mathrm{M}$ concentrations of tested compounds after $24 \mathrm{~h}$ of incubation. Data represent the means \pm SD from at least three independent experiments; ${ }^{*} p<0.05,{ }^{* *} p<0.01,{ }^{* * *} p<0.001,{ }^{* * * *} p<0.0001$, vs. unstimulated control cells. 


\subsection{Thymidine 5'-O-Monophosphorothioate as a Proangiogenic Nucleotide}

Considering the results of extracellular nucleotides' ability to release VEGF, the most preferred proangiogenic compound turned out to be TMPS. Additionally, this compound showed no cytotoxicity, and in the case of HUVECs, it slightly stimulated cellular proliferation. Besides, in our previous studies, we identified TMPS as an inhibitor UDP-glucose (UDPG)-induced degranulation in a rat mast cell line (degranulation of RBL-2H3). On the other hand, other nucleoside $5^{\prime}$-O-monophosphorothioate tested (AMPS, CMPS, UMPS) did not inhibit degranulation of mast cells and even caused enhancement of $N$-acetyl- $\beta$-Dhexosaminidase (a granule enzyme that parallels histamine release). Thus, inhibitors selectively preventing mast cell activation might prospectively offer novel anti-inflammatory therapeutic approaches [20].

Therefore, we decided to get further insight into how TMPS affects the mechanism of angiogenesis. We focused on the expression of exemplary genes, which play a role during vascularization (VEGFA) and extracellular matrix remodeling (MMP2). MMP2 is an essential member of the matrix metalloproteinase family, which mediates extracellular matrix remodeling and is a prerequisite for angiogenesis [21]. We also included MACF1 encoding microtubule actin cross-linking factor that plays an essential role in coordinating cell migration, cell proliferation, and maintenance of tissue integrity in the presence of F-actin and microtubules, critical for wound repair in skin epidermis [22]. We observed significant MMP2 mRNA level upregulation when HUVECs were treated with TMPS. MACF1 was also increased but to a less extend (Figure 5A). In turn, in human dermal fibroblasts, TMPS significantly increased mRNA levels of VEGFA (Figure 5B), supporting the results obtained for VEGF-A secretion in HDFs. MACF1 expression was also upregulated in both cell types studied.

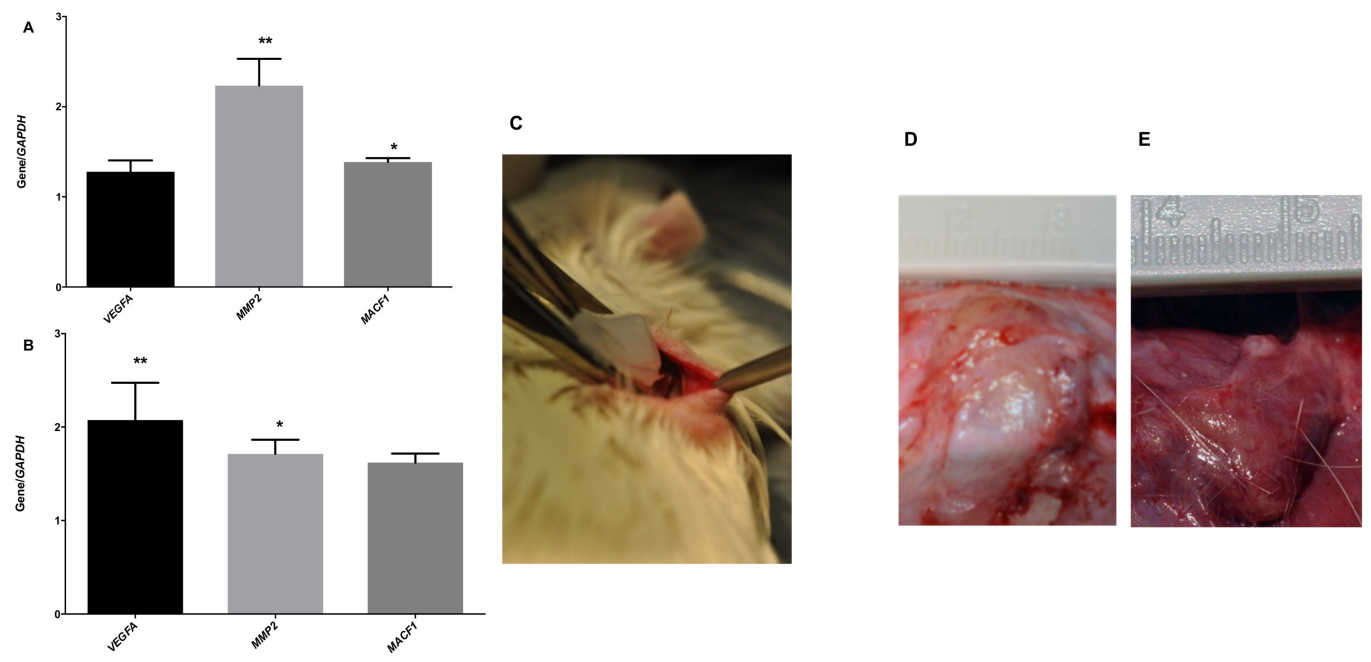

Figure 5. The influence of TMPS on VEGFA, MMP2, MACF1 expression in HUVECs (A) and HDF cells (B) and on angiogenesis in vivo. The subcutaneous implantations of BNC scaffolds were performed on the dorsal region of Wistar rats (C). Control BNC (D) and BNC with TMPS (E) were resected after 30 days, and macroscopic pictures were taken. The gene expression was analyzed by the $\Delta \Delta \mathrm{C}_{\mathrm{t}}$ method and was normalized to GAPDH for $100-\mu \mathrm{M}$ concentrations of TMPS. Data represent the means \pm SD from at least three independent experiments; ${ }^{*} p<0.05,{ }^{* *} p<0.01$ vs. unstimulated control cells.

Finally, we used TMPS to assess the possibility of promoting physiological hostmediated angiogenic response in vivo. Even though assays that monitor endothelial cell proliferation in in vitro culture benefit from being rapid, precise, and quantifiable, in vivo angiogenesis reflects a fully functional angiogenic process that works in tandem with various other processes. We employed a methodology based on implanting a polymer scaffold subcutaneously in the rat to monitor the angiogenic ingrowth. The scaffold material 
containing a test substance that should recruit host-derived endothelial cells is explanted at the end of the assay. Our studies used bionanocellulose (BNC) produced by Komagataeibacter xylinus as a scaffold because of its biocompatibility and high purity [23]. Two independent skin incisions about 1-cm-long were created on the back of Wistar rats and BNC with dimensions of $1 \times 1 \times 0.3 \mathrm{~cm}$ was implanted in each subcutaneous pouch (Figure $5 \mathrm{C}$ ). After suturing the wound edges, each rat was placed in a clean cage and subjected to daily observation. No rats showed signs of pain that the BNC scaffold implantation could have caused, and none of the rats showed signs of inflammation or infection. Finally, 30 days after implantation, BNC preparations were removed for macroscopic observation. Healthy tissues were observed surrounding the BNC with the presence of blood vessels. In the macroscopic photos taken during the resection, it was seen that in the case of TMPS-soaked BNC (Figure 5E), blood vessels and capillaries could be observed more extensively within the surrounding dermal tissue. The network of blood vessels was dense, with some of the vessels growing into the preparation (small capillaries were dominant).

\section{Discussion}

Wound healing is a biological process that involves interactions between cells, extracellular matrix components, and growth factors. Under physiological conditions, four stages in the healing process can be distinguished, hemostasis, inflammatory phase, proliferative phase, and scar remodeling. The individual phases overlap in time and space [24]. Besides the proliferation of fibroblasts and keratinocytes, angiogenesis is critical for wound healing, particularly after chronic or ischemic damage. Newly created blood vessels provide nutrition and oxygen to cells at the wound site. VEGF is a crucial element in vascular development, as it promotes angiogenesis by increasing endothelial cell survival, proliferation, and migration [25]. VEGF has been widely investigated in the context of cutaneous wound healing and was shown to be substantially increased in healing wounds. Treatment with VEGF inhibitors or genetic deletion of VEGF in keratinocytes resulted in delayed wound closure, demonstrating the overall relevance of VEGF in wound healing [26]. As a result, developing new strategies for therapeutic angiogenesis remains a critical priority for treating a range of wound healing deficits.

Application of exogenous nucleotides was shown to promote wound healing via the activation of purinergic receptors [12]. Activation of P2Y2 receptor by ATP or UTP was identified to induce the expression of the VEGF gene in fibroblasts [27]. In coronary artery endothelial cells, activated P2Y2 receptors transactivate VEGF receptor 2 (VEGFR-2), suggesting a direct link between extracellular nucleotides and angiogenesis [28]. In addition, activation of P2Y1 in endothelial cells promotes VEGFR-2 intracellular signaling to stimulate endothelial cell tubulogenesis [3]. P2Y1 and P2Y12- mediated activation of platelets by ADP also increased VEGF concentrations [4]. In turn, loss of P2Y4 receptor was associated with angiogenic defects and a microcardia phenotype [29]. Adenosine tetraphosphate (Up4A), endogenously released from endothelial cells, was identified to activate migration in smooth muscle cells from the thoracic aorta through activation of P2Y2 [30] and upregulate VEGFA gene and VEGF-A protein levels through purinergic P2Y receptors [31]. These findings clearly show that extracellular nucleotides are involved in angiogenesis by targeting purinergic receptors.

The limitation of natural nucleotides is their instability when administered in vivo [13]. However, we have shown that their phosphorothioate analogs are more resistant to enzymatic degradation [14]. Therefore, in the present study, we have investigated the potential proangiogenic action of unmodified and phosphorothioate analogs of nucleotides. 18 compounds were included, 8 of which were unmodified (TMP, UMP, UDP, UTP, CMP, AMP, ADP, ATP), and 10 were phosphorothioate analogs belonging to nucleoside $5^{\prime}-\mathrm{O}^{\prime}$ monophosphorothioates (TMPS, UMPS, CMPS, AMPS), 5'-diphosphorothioate (ADP $\beta S$, $\mathrm{UDP} \beta \mathrm{S})$, and $5^{\prime}$-triphosphorothioatea $(\operatorname{ATP} \alpha \mathrm{S}, \mathrm{ATP} \gamma \mathrm{S}, \mathrm{UTP} \alpha \mathrm{S}, \mathrm{UTP} \gamma \mathrm{S})$.

Our previous studies indicated that nucleoside $5^{\prime}$-O-phosphorothioate analogs, namely $\mathrm{UTP} \gamma \mathrm{S}, \mathrm{UTP} \alpha \mathrm{S}$, and ATP $\gamma \mathrm{S}$, accelerated VEGF release and migration of human HaCaT 
keratinocytes. The potencies were correlated with the highest $P 2 Y 2$ receptor expression by the HaCaT cell line [15]. In the present study, we tested the ability of a wide range of unmodified nucleotides (AMP, ADP, ATP, UMP, UDP, UTP, CMP, TMP) and their phosphorothioate analogs (AMPS, ADP $\beta$ S, ATP $\alpha$ S, ATP $\gamma$ S, UMPS, UDP $\beta$ S, UTP $\alpha$ S, UTP $\gamma$, CMPS, TMPS) to stimulate secretion of VEGF from fibroblasts. Additionally, the potency of nucleoside 5'-O-monophosphorothioates (TMPS, UMPS, CMPS, AMPS) was assessed in keratinocytes because previously we did not evaluate their activity in $\mathrm{HaCaT}$ cells. Our research was primarily focused on TMPS, UMPS, CMPS, and AMPS since earlier we have shown that nucleoside $5^{\prime}$-O-monophosphorothioates can also act as P2Y ligands [15,18]. We have evidenced that UMPS, CMPS, and AMPS act as P2Y14 agonists while TMPS serves as its antagonist [18]. Moreover, we have identified TMPS and UMPS as P2Y6 agonists [15]. On the other hand, AMPS appeared inactive as a P2Y6 agonist. However, it acted as a partial agonist of the P2Y11 receptor [32].

Previously, we also confirmed that the P2Y2 gene was the most abundant nucleotide receptor subtype in HaCaT cells. P2Y6 and P2Y1 expression were shown to be about two times lower. We also found mRNA for P2Y4 and P2Y11, as well as P2Y12, P2Y13, and $P 2 Y 14$ [15]. We identified a completely different expression profile of $P 2 Y$ in HUVECs and HDF cells. Among P2Y expressed in HUVEC cells, the highest expression level was noted for the P2Y6 gene. The analysis also showed relatively high P2Y1 and P2Y14 transcripts and a lower $P 2 Y 4, P 2 Y 2$, and $P 2 Y 11$. The research also confirmed the expression of $P 2 Y 1, P 2 Y 2, P 2 Y 4$, and $P 2 Y 6$, while in the case of $P 2 Y 1$ and $P 2 Y 6$, the level of detected transcripts was the highest. The high level of P2Y6 expression in human endothelial cells and fibroblasts was an additional reason to involve nucleoside $5^{\prime}$-O-monophosphorothioates in this study.

We initially evaluated the influence of tested nucleotides on the growth of human keratinocytes, fibroblasts, and endothelial cells. The unmodified nucleotides and their phosphorothioate analogs showed different abilities to stimulate cell survival and/or proliferation depending on the cell model used. The obtained results suggest that the tested compounds exert the most significant influence on the survival of the HaCaT line. UTP and $\mathrm{UTP} \alpha \mathrm{S}$ were the most effective in intensifying the metabolic activity of $\mathrm{HaCaT}$ cells and, to a lesser extent, in stimulating their proliferation. UDP and UDP $\beta S$, agonists of the P2Y6 receptor, have also shown stimulating activity among other uridine nucleotides. We have also proven the expression of this receptor in HaCaT cells, so it can be hypothesized that P2Y6 participates in the stimulation of cell survival. This hypothesis can also be supported by the fact that UTP and UTP $\alpha \mathrm{S}$, which were most active in these cells, could be hydrolyzed to UDP and UDP $\alpha$, respectively, and then activate the P2Y6 receptor. UTP $\gamma \mathrm{S}$, the most resistant to hydrolysis among uridine triphosphates tested, showed much lower activity. Particularly noteworthy is the activity of TMPS, UMPS, CMPS, and AMPS, which stimulated both the survival and proliferation of $\mathrm{HaCaT}$ keratinocytes. Unmodified nucleoside monophosphates did not exhibit such effects. Contrary to the $\mathrm{HaCaT}$, the impact of the tested nucleotides on the survival and proliferation of HDFs fibroblasts was less profound. The highest stimulation level observed for these cells was not higher than $20 \%$. Some compounds, particularly ADP and ATP and their phosphorothioate analogs, showed a significant effect in HUVECs, with ATP $\gamma \mathrm{S}$ being the most effective, probably activating $P 2 Y 2$ and/or $P 2 Y 11$ receptors. Literature data indicate that $P 2 Y 11$ is a more likely candidate because the phosphorothioate analog of ATP is a more potent receptor agonist than unmodified ATP [33]. A slight stimulation was also observed in HUVECs cultured in the presence of nucleoside $5^{\prime}$-O-monophosphorothioates.

Our previous studies revealed the high activity of UTP $\gamma \mathrm{S}, \mathrm{UTP} \alpha \mathrm{S}$, and ATP $\gamma \mathrm{S}$ to stimulate the secretion of the vascular endothelial growth factor by the HaCaT keratinocytes [15]. In this study, we demonstrate that stimulation of VEGF-A secretion is also observed in keratinocytes in the presence of nucleoside $5^{\prime}$-O-monophosphorothioates, mainly AMPS and TMPS. Surprisingly, nucleoside $5^{\prime}$-O-monophosphorothioates were the most potent concerning the production of VEGF-A by fibroblasts. These observations again support the 
hypothesis that nucleoside 5'-O-monothiophosphates may act as ligands for $P 2 Y$ nucleotide receptors. The unmodified nucleoside monophosphates did not induce similar effects.

TMPS appeared to be the most promisin concerning VEGF-A secretion among the nucleotides studied. We showed previously that in a stable P2Y14-expressing HEK293T cell line, TMPS inhibited UDPG-induced activation of the P2Y14 receptor [14]. TMPS also suppressed UDPG-evoked degranulation in antigen-sensitized RBL-2H3 mast cells. Importantly, UMPS, CMPS, and AMPS acted as activating compounds for the P2Y14 receptor. On the other hand, our studies also proved that TMPS stimulated cellular migration targeting the P2Y6 receptor [20]. Here, we show the preliminary results that confirm the proangiogenic activity of TMPS under in vivo conditions. One can hypothesize that this activity is correlated with their binding to and activation of the P2Y 6 receptor. However, activation of receptors by $5^{\prime}$-O-monophosphorothioates may not be the only signaling pathway involved in the formation of new blood vessels during our experiments with Wistar rats. Another purinergic signaling cascade mediates the hydrolysis of ATP into ADP, $\mathrm{AMP}$, and finally, adenosine which activates $\mathrm{P} 1$ receptors responsible for promoting many essential processes, including angiogenesis and VEGF release. A vital component of this purinergic system is the enzyme ecto-5-nucleotidase (CD73), which catalyzes the last step in the extracellular metabolism of ATP to form adenosine. A recent review by Alcedo et al. presents this enzyme as a critical regulator of cellular homeostasis, stress responses, injury, and disease mechanisms across many tissues [34]. While AMP is the primary substrate of the enzyme, CD73 has been reported to hydrolyze also other $5^{\prime}$-nucleoside monophosphates [35]. Although the activity of CD73 towards $5^{\prime}$-nucleoside monophosphorothioates has not been reported so far, one can suggest that these compounds may be relatively inefficient in enzyme inhibition. Therefore, this alternative signaling pathway CD73adenosine-P1 receptors should not be influenced by $5^{\prime}$-NMPS and could participate in forming new blood vessels at the BNC scaffold surface.

The ability of TMPS and other nucleotides to augment VEGF secretion is of particular importance. However, recent research suggests that VEGF may potentially act as a profibrotic mediator. During the final phases of wound healing, fibroblasts deposit and restructure collagen to rebuild the dermal layer of the skin, eventually generating a mature scar. In most circumstances, a normal scar will form; however, when fibroblasts create an excessive amount of collagen, aberrant scars such as hypertrophic scars and keloids might occur [36]. Several studies have found a relationship between scar formation and robust angiogenesis. Although the particular mechanisms through which VEGF promotes scar formation are unknown, endothelial cell stimulation or inflammation amplification, as well as possible effects on fibroblasts, have been proposed [37]. Some reports demonstrate the significant contribution of extracellular nucleosides and nucleotides in promoting abnormal matrix production and generate questions on the risk of hypertrophic scars. Excessive ligand-mediated activation of specific nucleoside and nucleotide receptors gives the tissue microenvironment a surplus of signals, promoting abnormal replication of smooth muscle cells, fibroblasts, and myofibroblasts pathologic matrix deposition causing fibrosis [38]. Because we observed that the proliferation of human dermal fibroblasts was only slightly stimulated by most of the nucleotides tested, one could suggest their role in decreasing the risk of hypertrophic scars. However, at present, this field is at an initial stage and many developments have still to be made.

Another issue that has to be emphasized in hypertrophic scar formation is connected with mast cells activation, which leads to the release of newly synthesized mediators [39]. Histamine released from mast cells increases capillary permeability and vasodilation, allowing neutrophils to enter the wound and other mediators such as IL-4 and basic fibroblast growth factor to increase fibroblast proliferation [40]. In addition, mast cell tryptase stored in granules of activated mast cells has chemotactic and mitogenic effects on fibroblasts and participates in collagen synthesis, contraction, and differentiation into myofibroblasts [41]. Because our previous studies demonstrated that TMPS has a unique ability to antagonize 
P2Y14 receptor in mast and thereby inhibited mast cell degranulation [18], one can presume that this activity may contribute to anti-profibrotic activity.

The possible application of nucleoside $5^{\prime}$-O-phosphorothioate analogs in the treatment of chronic wounds is also questionable. In general, we see no need for nucleotides to be applied to acute injuries since an initial powerful angiogenic response is characteristic for normally healing acute wounds [42]. Recently, topically applied adenosine-5'-diphosphate was shown to improve the wound healing of diabetic mice but not of healthy nondiabetic animals, which are already highly competent in tissue repair [43]. However, inadequate angiogenesis has been linked to the pathology of chronic wounds, including diabetic wounds, pressure ulcers, and wounds of individuals with venous stasis disease [42]. Several studies have also demonstrated substantial differences with angiogenesis between younger and older people during wound healing [44]. Therefore, the application of TMPS in chronic wounds should be considered especially that we demonstrated that nucleoside $5^{\prime}$ O-phosphorothioate analogues are better candidates to overcome hyperglycaemia-induced impairment of angiogenesis as compared to unmodified counterparts [15]. Besides, an increase in ecto-nucleotidase activity was observed in patients with diabetes and associated pathologies [44]. These observations strongly support the advantage of nucleoside $5^{\prime}-\mathrm{O}-$ phosphorothioate analogs over unmodified nucleotides also in terms of their increased stability and resistance toward the ecto- $5^{\prime}$-nucleotidase present at the cell surface [45].

In this way, we provide new indications that nucleoside $5^{\prime}$-O-phosphorothioate analogs can cause an improvement in the healing of chronic wounds, especially those related to advanced age and diabetes. However, relevant scientific and clinical questions on the role of phosphorothioate nucleotides in wound healing are awaiting an answer. We are aware that the findings of this study have to be seen in the light of some limitations. Several studies suggest that some capillaries formed in early healing wounds are not highly functional, e.g., effectively perfused. Besides, new capillaries produced under high proangiogenic pressure situations, such as in solid malignancies, were shown to be leaky and often ineffective in delivering adequate blood flow [42]. Therefore, further studies assessing if phosphorothioate nucleotides such as TMPS stimulate the formation of functional vasculature with proper perfusion are necessary. More work has to be done with in vivo studies and clinical testing. Finally, characteristics of the patient, such as age and other conditions such as diabetes that might increase the risk of wound healing complications, would have to be also carefully considered.

In summary, the results of this research demonstrate that the presence of extracellular nucleotides, especially phosphorothioate analogs, induces the proangiogenic behavior of fibroblasts, keratinocytes, and endothelial cells. Among investigated compounds, the activity of thymidine $5^{\prime}$-O-monophosphorothioate seems very promising (Figure 6). Our study provides evidence for TMPS-mediated efficient release of VEGF-A from human dermal fibroblasts and keratinocytes accompanied by the augmented expression of MMP2 and MACF1 in HUVECS. TMPS also stimulated both the survival and proliferation of HaCaT cells and HDFs and the formation of new blood vessels in a rat model with subcutaneously implanted TMPS-soaked BNC biomaterial. We propose that thymidine 5'-O-monophosphorothioate may be a new candidate for accelerating healing in cutaneous wounds, especially since we have proven previously that TMPS is the antagonist of P2Y14 involved in inflammatory signaling. These findings suggest that TMPS possesses a promising therapeutic potential in vascular diseases, particularly for patients with chronic skin wounds. However, relevant scientific and clinical questions on the role of phosphorothioate analogs of nucleotides in wound healing are awaiting an answer. 


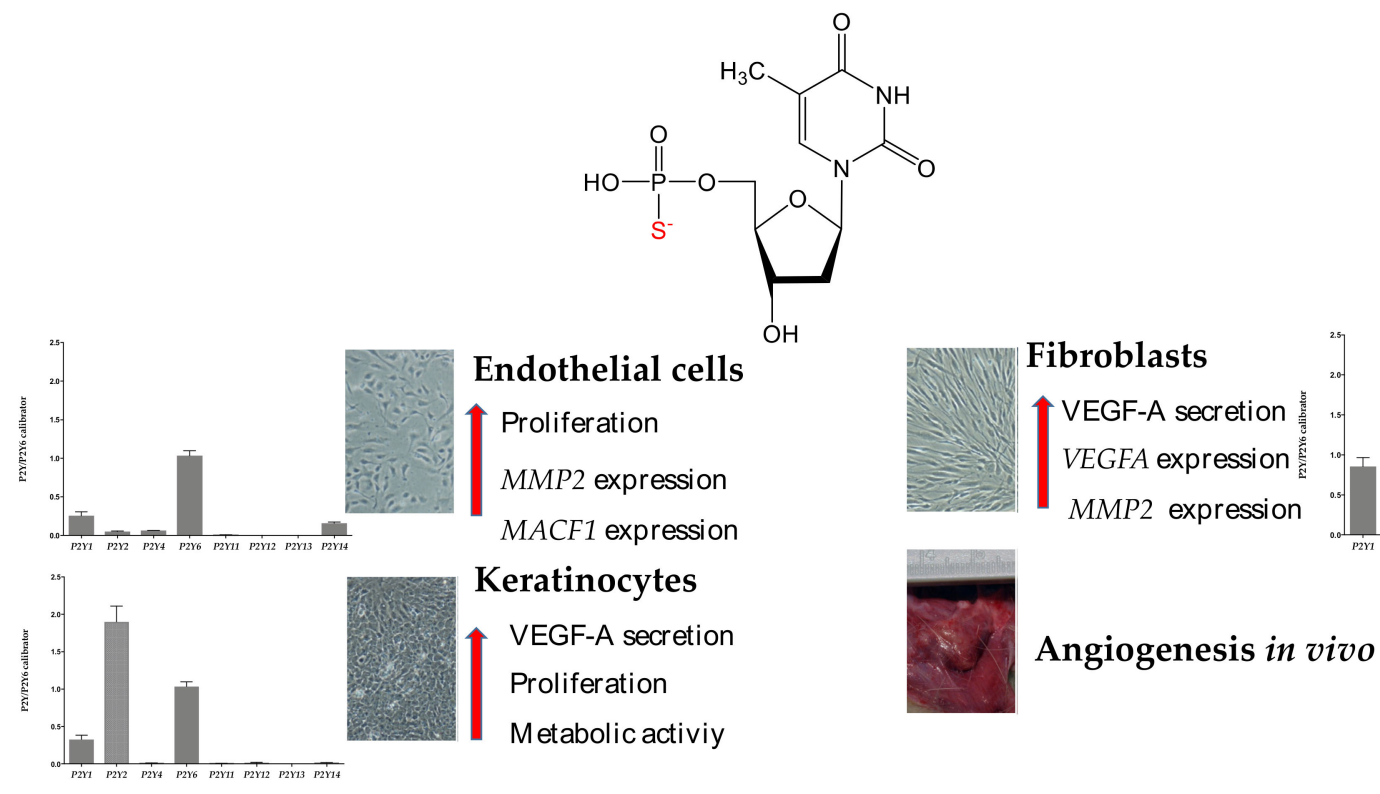

Figure 6. TMPS affects the proangiogenic behavior of fibroblasts, keratinocytes, and endothelial cells through stimulation of (1) VEGF-A secretion from HaCaT keratinocytes and human dermal fibroblasts, (2) VEGFA expression in fibroblasts, (3) MMP2 expression in HUVECs and HDFs, (4) MACF1 expression in HUVECs, (5) proliferation of HUVECs and HDFs, and (6) metabolic activity in HaCaT. TMPS also promotes host-mediated angiogenic response in vivo. The expression pattern of $P 2 Y$ receptors in cells under study is also shown.

Author Contributions: Conceptualization, E.G.-D.; methodology, E.G.-D., E.W.; formal analysis, S.B.; investigation, E.W., D.K., B.G., D.P., M.K. (Marek Kołodziejczyk); resources, E.W., M.K. (Maria Koziołkiewicz); writing-original draft preparation, E.G.-D., M.K. (Maria Koziołkiewicz); writing—revised draft preparation, E.G.-D., M.K. (Maria Koziołkiewicz); visualization, E.G.-D., D.K.; supervision, E.G.-D.; project administration, E.G.-D.; funding acquisition, E.G.-D. All authors have read and agreed to the published version of the manuscript.

Funding: This research was financially supported by the Ministry of Science and Higher Education (Project No. N 405304736 to E.G.D.).

Data Availability Statement: Data from this study is secured in a password protected computer in the Institute of Molecular and Industrial Biotechnology, Lodz University of Technology, Poland.

Acknowledgments: This work has been completed while the third author was the Doctoral Candidate in the Interdisciplinary Doctoral School at the Lodz University of Technology, Poland.

Conflicts of Interest: The authors declare no conflict of interest.

\section{Abbreviations}

ADP Adenosine $5^{\prime}$-O-diphosphate

ADP $\beta S$ Adenosine 5'-O- $\beta$-thiodiphosphate

AMP Adenosine 5'-O-monophosphate

AMPS Adenosine 5'-O-thiomonophosphate

ADP Adenosine 5'-O-diphosphate

ADP $\beta S$ Adenosine $5^{\prime}$-O- $\beta$-thiodiphosphate

ATP Adenosine $5^{\prime}$-O-triphosphate

ATP $\alpha S \quad$ Adenosine $5^{\prime}-\mathrm{O}-\alpha$-thiotriphosphate

ATP $\gamma \mathrm{S}$ Adenosine 5'-O- $\gamma$-thiotriphosphate

CMP Cytidine 5'-O-monophosphate

CMPS Cytidine 5'-O-thiomonophosphate

DMEM Dulbecco's modified Eagle medium

FBS Fetal Bovine Serum

PBS Phosphate-buffered saline 


$\begin{array}{ll}\text { RT-qPCR } & \text { Reverse transcription quantitative polymerase chain reaction } \\ \text { TMP } & \text { Thymidine 5'-O-monophosphate } \\ \text { TMPS } & \text { Thymidine 5'-O-thiomonophosphate } \\ \text { UDP } & \text { Uridine 5'-O-diphosphate } \\ \text { UDP } \beta S & \text { Uridine 5'-O- } \beta \text {-thiodiphosphate } \\ \text { UMP } & \text { Uridine 5'-O-monophosphate } \\ \text { UMPS } & \text { Uridine 5'-O-thiomonophosphate } \\ \text { UTP } & \text { Uridine 5'-O-triphosphate } \\ \text { UTP } \alpha S & \text { Uridine } 5 \text {-O- } \alpha \text {-thiotriphosphate } \\ \text { UTP } \gamma S & \text { Uridine } 5^{\prime}-\mathrm{O}-\gamma \text {-thiotriphosphate }\end{array}$

\section{References}

1. Neumann, A.; Müller, C.E.; Namasivayam, V. P2Y 1 -like nucleotide receptors-Structures, molecular modeling, mutagenesis, and oligomerization. Wiley Interdiscip. Rev. Comput. Mol. Sci. 2020, 10, e1464. [CrossRef]

2. Erb, L.; Weisman, G.A. Coupling of P2Y receptors to G proteins and other signaling pathways. Wiley Interdiscip. Rev. Membr. Transp. Signal. 2012, 1, 789-803. [CrossRef] [PubMed]

3. Rumjahn, S.M.; Yokdang, N.; Baldwin, K.A.; Thai, J.; Buxton, I.L.O. Purinergic regulation of vascular endothelial growth factor signaling in angiogenesis. Br. J. Cancer 2009, 100, 1465-1470. [CrossRef] [PubMed]

4. Bambace, N.M.; Levis, J.E.; Holmes, C.E. The effect of P2Y-mediated platelet activation on the release of VEGF and endostatin from platelets. Platelets 2010, 21, 85-93. [CrossRef] [PubMed]

5. Sorop, O.; Olver, T.D.; van de Wouw, J.; Heinonen, I.; van Duin, R.W.; Duncker, D.J.; Merkus, D. The microcirculation: A key player in obesity-associated cardiovascular disease. Cardiovasc. Res. 2017, 113, 1035-1045. [CrossRef]

6. Kolluru, G.K.; Bir, S.C.; Kevil, C.G.; Calvert, J.W. Endothelial Dysfunction and Diabetes: Effects on Angiogenesis, Vascular Remodeling, and Wound Healing. Int. J. Vasc. Med. 2012, 2012, 918267. [CrossRef] [PubMed]

7. Lauer, G.; Sollberg, S.; Cole, M.; Krieg, T.; Eming, S.A.; Flamme, I.; Stürzebecher, J.; Mann, K. Expression and Proteolysis of Vascular Endothelial Growth Factor is Increased in Chronic Wounds. J. Investig. Dermatol. 2000, 115, 12-18. [CrossRef]

8. Eming, S.A.; Lauer, G.; Cole, M.; Jurk, S.; Christ, H.; Hornig, C.; Krieg, T.; Weich, H.A. Increased levels of the soluble variant of the vascular endothelial growth factor receptor VEGFR-1 are associated with a poor prognosis in wound healing. J. Investig. Dermatol. 2004, 123, 799-802. [CrossRef]

9. Papanas, N.; Maltezos, E. Growth factors in the treatment of diabetic foot ulcers: New technologies, any promises? Int. J. Low. Extrem. Wounds 2007, 6, 37-53. [CrossRef]

10. Das, S.; Singh, G.; Baker, A.B. Overcoming disease-induced growth factor resistance in therapeutic angiogenesis using recombinant co-receptors delivered by a liposomal system. Biomaterials 2014, 35, 196-205. [CrossRef]

11. Veith, A.; Henderson, K.; Spencer, A.; Sligar, A.D.; Baker, A.B. Therapeutic strategies for enhancing angiogenesis in wound healing. Adv. Drug Deliv. Rev. 2018, 146, 97-125. [CrossRef]

12. Gendaszewska-Darmach, E.; Kucharska, M. Nucleotide receptors as targets in the pharmacological enhancement of dermal wound healing. Purinergic Signal. 2011, 7, 193-206. [CrossRef]

13. Zimmermann, H.; Zebisch, M.; Sträter, N. Cellular function and molecular structure of ecto-nucleotidases. Purinergic Signal. 2012, 8, 437-502. [CrossRef] [PubMed]

14. Gendaszewska-Darmach, E.; Szustak, M. Thymidine 5'-O-monophosphorothioate induces HeLa cell migration by activation of the P2Y6 receptor. Purinergic Signal. 2016, 12, 199-209. [CrossRef] [PubMed]

15. Węgłowska, E.; Szustak, M.; Gendaszewska-Darmach, E. Proangiogenic properties of nucleoside 5'-O-phosphorothioate analogues under hyperglycaemic conditions. Curr. Top. Med. Chem. 2015, 15, 2464-2474. [CrossRef]

16. Patel, G.K.; Wilson, C.H.; Harding, K.G.; Finlay, A.Y.; Bowden, P.E. Numerous keratinocyte subtypes involved in wound re-epithelialization. J. Investig. Dermatol. 2006, 126, 497-502. [CrossRef]

17. Gendaszewska-Darmach, E.; Węgłowska, E.; Walczak-Drzewiecka, A.; Karaś, K. Nucleoside 5'-O-monophosphorothioates as modulators of the P2Y14 receptor and mast cell degranulation. Oncotarget 2016, 7, 69358-69370. [CrossRef] [PubMed]

18. Quent, V.M.C.; Loessner, D.; Friis, T.E.; Reichert, J.C.; Hutmacher, D.W. Discrepancies between metabolic activity and DNA content as tool to assess cell proliferation in cancer research. J. Cell. Mol. Med. 2010, 14, 1003-1013. [CrossRef]

19. Jones, L.J.; Gray, M.; Yue, S.T.; Haugland, R.P.; Singer, V.L. Sensitive determination of cell number using the CyQUANT®cell proliferation assay. J. Immunol. Methods 2001, 254, 85-98. [CrossRef]

20. Sun, C.; Feng, S.-B.; Cao, Z.-W.; Bei, J.-J.; Chen, Q.; Xu, X.-J.; Zhou, Z.; Yu, Z.-P.; Hu, H.-Y. Up-Regulated Expression of Matrix Metalloproteinases in Endothelial Cells Mediates Platelet Microvesicle-Induced Angiogenesis. Cell. Physiol. Biochem. 2017, 41, 2319-2332. [CrossRef]

21. Miao, Z.; Ali, A.; Hu, L.; Zhao, F.; Yin, C.; Chen, C.; Yang, T.; Qian, A. Microtubule actin cross-linking factor 1, a novel potential target in cancer. Cancer Sci. 2017, 108, 1953-1958. [CrossRef]

22. Irvin, M.W.; Zijlstra, A.; Wikswo, J.P.; Pozzi, A. Techniques and assays for the study of angiogenesis. Exp. Biol. Med. 2014, 239, 1476-1488. [CrossRef] 
23. Szustak, M.; Gendaszewska-Darmach, E. Nanocellulose-Based Scaffolds for Chondrogenic Differentiation and Expansion. Front. Bioeng. Biotechnol. 2021, 9, 733. [CrossRef]

24. Gurtner, G.C.; Werner, S.; Barrandon, Y.; Longaker, M.T. Wound repair and regeneration. Nature 2008, 453, 314-321. [CrossRef] [PubMed]

25. Rey, S.; Semenza, G.L. Hypoxia-inducible factor-1-dependent mechanisms of vascularization and vascular remodelling. Cardiovasc. Res. 2010, 86, 236-242. [CrossRef]

26. Jin, H.; Seo, J.; Eun, S.Y.; Joo, Y.N.; Park, S.W.; Lee, J.H.; Chang, K.C.; Kim, H.J. P2Y2R activation by nucleotides promotes skin wound-healing process. Exp. Dermatol. 2014, 23, 480-485. [CrossRef]

27. Seye, C.I.; Yu, N.; González, F.A.; Erb, L.; Weisman, G.A. The P2Y2 nucleotide receptor mediates vascular cell adhesion molecule-1 expression through interaction with VEGF receptor-2 (KDR/Flk-1). J. Biol. Chem. 2004, 279, 35679-35686. [CrossRef]

28. Horckmans, M.; Robaye, B.; Léon-Gómez, E.; Lantz, N.; Unger, P.; Dol-Gleizes, F.; Clouet, S.; Cammarata, D.; Schaeffer, P.; Savi, P.; et al. P2Y4 nucleotide receptor: A novel actor in post-natal cardiac development. Angiogenesis 2012, 15, 349-360. [CrossRef] [PubMed]

29. Wiedon, A.; Tölle, M.; Bastine, J.; Schuchardt, M.; Huang, T.; Jankowski, V.; Jankowski, J.; Zidek, W.; van der Giet, M. Uridine adenosine tetraphosphate $(\mathrm{Up} 4 \mathrm{~A})$ is a strong inductor of smooth muscle cell migration via activation of the P2Y2 receptor and cross-communication to the PDGF receptor. Biochem. Biophys. Res. Commun. 2011, 417, 1035-1040. [CrossRef]

30. Zhou, Z.; Chrifi, I.; Xu, Y.; Pernow, J.; Duncker, D.J.; Merkus, D.; Cheng, C. Uridine adenosine tetraphosphate acts as a proangiogenic factor in vitro through purinergic P2Y receptors. Am. J. Physiol. Circ. Physiol. 2016, 311, H299-H309. [CrossRef] [PubMed]

31. Communi, D.; Robaye, B.; Boeynaems, J.-M. Pharmacological characterization of the human P2Y11 receptor. Br. J. Pharmacol. 1999, 128, 1199-1206. [CrossRef] [PubMed]

32. Jacobson, K.A.; Ivanov, A.A.; de Castro, S.; Harden, T.K.; Ko, H. Development of selective agonists and antagonists of P2Y receptors. Purinergic Signal. 2008, 5, 75-89. [CrossRef] [PubMed]

33. Alcedo, K.P.; Bowser, J.L.; Snider, N.T. The elegant complexity of mammalian ecto-5' ${ }^{\prime}$-nucleotidase (CD73). Trends Cell Biol. 2021, 31, 829-842. [CrossRef]

34. Scaletti, E.; Huschmann, F.U.; Mueller, U.; Weiss, M.S.; Sträter, N. Substrate binding modes of purine and pyrimidine nu-cleotides to human ecto-5'-nucleotidase (CD73) and inhibition by their bisphosphonic acid derivatives. Purinergic Signal. 2021, 1, 1-12 [CrossRef]

35. Wilgus, T.A. Vascular Endothelial Growth Factor and Cutaneous Scarring. Adv. Wound Care 2019, 8, 671-678. [CrossRef]

36. Mogili, N.S.; Krishnaswamy, V.R.; Jayaraman, M.; Rajaram, R.; Venkatraman, A.; Korrapati, P.S. Altered angiogenic balance in keloids: A key to therapeutic intervention. Transl. Res. 2011, 159, 182-189. [CrossRef]

37. Wilgus, T.A.; Ferreira, A.M.; Oberyszyn, T.M.; Bergdall, V.K.; DiPietro, L.A. Regulation of scar formation by vascular endothelial growth factor. Lab. Investig. 2008, 88, 579-590. [CrossRef] [PubMed]

38. Ferrari, D.; Gambari, R.; Idzko, M.; Müller, T.; Albanesi, C.; Pastore, S.; La Manna, G.; Robson, S.C.; Cronstein, B. Purinergic signaling in scarring. FASEB J. 2015, 30, 3-12. [CrossRef] [PubMed]

39. Ng, M.F. The role of mast cells in wound healing. Int. Wound J. 2010, 7, 55-61. [CrossRef] [PubMed]

40. Kennelly, R.; Conneely, J.B.; Bouchier-Hayes, D.; Winter, D.C. Mast Cells in Tissue Healing: From Skin to the Gastrointestinal Tract. Curr. Pharm. Des. 2011, 17, 3772-3775. [CrossRef]

41. Blank, U.; Madera-Salcedo, I.K.; Danelli, L.; Claver, J.; Tiwari, N.; Sãnchez-Miranda, E.; Vãzquez-Victorio, G.; Ramã rez-Valadez, K.A.; Macias-Silva, M.; Gonzãlez-Espinosa, C. Vesicular Trafficking and Signaling for Cytokine and Chemokine Secretion in Mast Cells. Front. Immunol. 2014, 5, 453. [CrossRef]

42. DiPietro, L.A. Angiogenesis and scar formation in healing wounds. Curr. Opin. Rheumatol. 2013, 25, 87-91. [CrossRef] [PubMed]

43. Borges, P.A.; Waclawiak, I.; Georgii, J.L.; Fraga-Junior, V.D.S.; Barros, J.F.; Lemos, F.S.; Russo-Abrahão, T.; Saraiva, E.M.; Takiya, C.M.; Coutinho-Silva, R.; et al. Adenosine Diphosphate Improves Wound Healing in Diabetic Mice Through P2Y12 Receptor Activation. Front. Immunol. 2021, 12, 793. [CrossRef] [PubMed]

44. Lunkes, G.I.; Lunkes, D.; Stefanello, F.; Morsch, A.; Morsch, V.M.; Mazzanti, C.M.; Schetinger, M.R.C. Enzymes that hydrolyze adenine nucleotides in diabetes and associated pathologies. Thromb. Res. 2003, 109, 189-194. [CrossRef]

45. Koziołkiewicz, M.; Gendaszewska, E.; Maszewska, M.; Stein, C.A.; Stec, W.J.; Drbal, K.; Angelisová, P.; Hilgert, I.; Černý, J.; Novák, P.; et al. The mononucleotide-dependent, nonantisense mechanism of action of phosphodiester and phosphorothioate oligonucleotides depends upon the activity of an ecto-5'-nucleotidase. Blood 2001, 98, 995-1002. [CrossRef] 